\title{
EKSISTENSI DAN PARTISIPASI MAJELIS ULAMA INDONESIA DALAM PENGEMBANGAN HUKUM ISLAM
}

\author{
Fatroyah Asr Himsyah \\ Fakultas Syari'ah UIN Maliki Malang \\ Telepon: 085649549933
}

\begin{abstract}
Abstrak
Hukum Islam sejatinya berputar mengalami perkembangan sesuai dengan perkembangan zaman, dengan berbagai hal baru yang semakin komplek yang membutuhkan legitimasi hukum Islam. Maka, sudah menjadi dasar dari hukum Islam sendiri sebagai wujud riil dari "shalihun fikulli zaman wal makan" merespon permasalahnpermasalahan tersebut. Ulama, sebagai kunci utama dalam menjalankan perguliran roda hukum Islam ini menjadi hal terpenting untuk menghindari kembali kejumudan hukum yang pernah terjadi pada beberapa dekade lalu dalam dunia Islam. Terbentuknya Majelis Ulama Indonesia sebagai organisasi masyarakat yang menampung berbagai variasi permasalahan yang telah banyak bermunculan, dirasa sangat tepat keberadaannya. Akan tetapi, posisinya saat ini, saling tarik ulur, antara pemerintah dan masyarakat. Bagaimana keberadaan MUI ini menjalankan fungsinya dalam penyebaran hukum Islam di Indonesia, menjadi topik yang menarik untuk diangkat dalam tulisan ini.

Islamic law always changes and develops based on the developing of the ages where there are varieties of dynamic problems which need Islamic law legitimacy. Therefore, the Islamic law which is addressed as "shalihun fikulli zaman wal makan" must response those problems especially modern problems. Ulama, as an eminent key in turning of Islamic law, becomes important for avoiding Islamic law rigidities as happened previously in Islamic world. The founding of Majelis Ulama Indonesia (MUI) as society organization which accommodates some problems is very crucial. However, its position is still problematic due to its duty to accommodate two sides, government and society. This position will influence how MUI runs its functions in distributing of Fatwa as Islamic law product in Indonesia. That problem becomes the main topic which is explored in this paper.
\end{abstract}

Kata kunci: hukum Islam, pemerintahan, masyarakat

Hukum, merupakan suatu hal yang bersifat dinamis. Dalam perkembangannya hukum merupakan akibat dari berbagai aspek, keadaan dan situasi yang ada pada suatu tempat dan dalam kurun waktu yang ada. Tak terkecuali dengan hukum Islam, yang mengalami perkembangan sejak awal kemunculannya sebagai suatu syariat yang mengatur segala jenis aspek kehidupan bahkan tidak hanya pada zaman pasca disempurnakannya agama Islam tersebut bahkan jauh hingga berakhirnya zaman.

Seiring dengan berkembangnya zaman dan manusia, sudah barang tentu permasalahan yang muncul semakin kompleks, sehingga menuntut sebuah penalaran fiqh untuk menjawab permasalahan-permasalahan tersebut. Ijtihad sebagai salah satu metode dalam pengistinbathan hukum harus memiliki apresiasi dan aplikasi dalam hal ini dengan kerangka produk setting dan budaya lokal, agar fiqh menjadi produk hukum sezaman.

Dapat dikatakan bahwa ijtihad merupakan sebuah keharusan dizaman modern ini. Sebagaimana kita ketahui bahwa ada banyak kontroversi kemungkinan ijtihad ini dilakukan pada saat ini mengingat 
perihal tentang adanya seseorang yang dianggap mumpuni untuk menjadi seorang mujtahid kini telah jarang ditemui. Namun di samping itu, keberadaan ulama memiliki peranan yang sangat signifikan dalam kehidupan sosial agama. Secara moralitas dan intelektualitas, ulama memiliki tanggung jawab atas perubahan dan perkembangan sosial keagamaan masyarakat khususnya umat Islam.

Keberadaan Majelis Ulama Indonesia (MUI) saat ini yang dikenal sebagai wadah perhimpunan para ulama dalam menjalankan fungsinya menanggapi dinamika permasalahan di Indonesia, dinilai sebagi salah satu tindakan yang positif. Upaya pemberian fatwa-fatwa yang selama ini telah dilakukan tentunya memberikan dampak bagi keberlangsungan jalannya negara Indonesia dengan berbagai komponen di dalamnya baik politik maupun tatanan sosial yang ada.

Dikatakan demikian, karena dengan terbentuknya MUI sebagai lembaga yang identik dengan tugasnya dalam memproduk fatwa, maka Indonesia dapat digolongkan sebagai negara yang mencoba mengkompromikan antara hukum sekuler (hukum Belanda yang diadopsi Indonesia) dengan hukum syari'at pada waktu yang bersamaan. Keberadaan MUI yang pernah diibaratkan sebagai "kue bika" memposisikan bahwa keberadaan MUI sebagai ormas (organisasi masyarakat) tidaklah murni sebagaimana organisasi masyarakat pada umumnya. Posisi MUI yang senyatanya berada pada dua iklim, antara iklim birokratis dan sosietis, menjadi pusat perhatian yang menarik untuk kemudian ditelusuri bagaimana fatwa-fatwa MUI tersebut menjawab permasalahan kontemporer di negara ini, dan peran yang dimainkannya dalam kehidupan masyarakat sekarang ini.

\section{HASIL DAN PEMBAHASAN}

\section{Hasil}

Indonesia merupakan negara pemilik penduduk Islam terbesar di dunia. Sekalipun jumlah penduduk muslimnya begitu besar, namun negara ini tidak menjalankan hukum-hukum Islam sebagai hukum formal negara. Akan tetapi, hukumhukum formal yang ada secara syah dan tekstual melindungi eksistensi dari hukum Islam sendiri, hal ini disebabkan negara Indonesia memiliki tidak hanya satu agama yang dianut oleh penduduknya, selain itu sistem hukum yang adapun telah mengenal adanya hukum adat jauh sebelum Islam masuk, dimana hingga kini hukum adat tetap eksist keberadaannya di tengah-tengah masyarakat Indonesia

Berkaitan dengan nilai keagamaan di Indonesia dengan keadaan hukum Islam sendiri, Muhammad Atho Mudzhar menyebutkan paling tidak ada empat aspek yang harus disinggahi untuk mengetahui hal tersebut, antara lain: sejarah budaya, doktrin teologi, susunan sosial, dan ideologi politik.[1]

Dari segi kebudayaan, Islam mampu menampung per-adat-an Hindu pada masa awal masuknya Islam ke Indonesia, hingga pada abad kesembilan belas dan kedua puluh, kaum muslim masih mempertahankan sisa kebudayaan Hindu tersebut dan menjadi golongan Islam abangan dalam masyarakat Islam, sebagai tandingan kaum santri. Menyusul kemudian, adanya golongan priyayi, dimana ketiganya dinilai saling bertentangan satu sama lain dalam pandangan politik dan ideologi.[2] Berdasarkan doktrin keagamaan, kaum muslim Indonesia tergolong sebagai penganut teologi Asy'ari dan madzhab Syafi'I, dengan sendirinya pula mereka mengaku dalam golongan ahlu sunnah wal jama'ah. Keadaan ini lambat laun mengalami pergeseran dengan munculnya dua organisasi ulama yang berbeda haluan (antara modem dan tradisional) yakni Muhammadiyah dan Nahdlatul Ulama. Pada tingkat struktur sosial, dapat dikatakan kaum muslim Indonesia tidak mengenal adanya hierarki keagamaan, sebab sekalipun terdapat majelis-majelis ulama dari tingkat nasional, ada ulama tertentu yang lebih dihor-

[1] Mohammad Atho Mudzhar, Fatwa-Fatwa Majelis Ulama Indonesia Sebuah Studi Tentang

Pemikiran Hukum Islam di Indonesia (Jakarta: INIS, 1993), 12.

[2]Mohammad Atho Mudzhar, Fatwa-Fatwa, 19. 
mati sekalipun bukan termasuk pengurus majelis. Dalam praktiknya, kaum Muslim umumnya dan pedesaan khususnya memperlihatkan adanya kesetiaan dan penghormatan yang tinggi pada ulama setempat, sehingga keberadaan ulama ini sangat berpengaruh pada masyarakat.[3]

Adapun dari segi politik ideologis, peran masyarakat muslim juga memiliki andil yang cukup signifikan, menengok sejarah bahwa upaya memerdekakan Indonesia dari penjajahan tidak lepas dari upaya perjuangan kaum Muslim, seperti pada perang Padri (1821-1827), Perang Diponegoro (1825-1830), Perang Bone (1835), dan Perang Aceh (1871-1908).[4] Lebih lanjut, dengan terbentuknya MIAI (Majelis Islam A'la Indonesia) yang kemudian diganti dengan Masyumi yang tidak lama setelah itu dibubarkan, hingga pada masa Soeharto terbentuklah kembali himpunan Ulama, selanjutnya dan hingga saat ini disebut dengan Majelis Ulama Indonesia (MUI). Secara konseptual hukum Islam dipersepsi sebagai suatu hukum yang universal, dinamis, elastis, fleksibel, dan dapat beradaptasi, dan berinteraksi serta dapat menampung berbagai bentuk perkembangan dimana saja dan kapan saja. Penerapan prinsip-prinsip tersebut dalam tataran empirik historis telah melahirkan otak-otak besar dan karya-karya monumental dalam bidang pemikiran hukum Islam sesuai dengan tingkat perkembangan masyarakatnya dan tuntutan sosio -kultural yang mengitarinya.[5]

Fiqh yang mengandung prinsip-prinsip universal hukum Islam di dalamnya dengan tuntutan pranata sosial dan realitas berbagai wilayah Islam, kemudian dengan tuntutan tersebut muncullah fiqh-Hijaz, yakni fiqh yang terbentuk atas dasar adat-istiadat yang berlaku di Hijaz, fiqhMesir yakni figh yang bersentuhan dengan sosiokultural Mesir, fiqh-Hindi yakni fiqh yang terbentuk atas dasar dan sumber pada 'urf yang berlaku di India, dan fiqh-Iraq yakni fiqh yang ber-

[3]Mohammad Atho Mudzhar, Fatwa-Fatwa, 26.

[4]Mohammad Atho Mudzhar, Fatwa-Fatwa, 27.

[5]Amir Mu'allim dan Yusdani, Ijtihad dan Legislasi Muslim Kontemporer (Yogyakarta: UII Press, 2005), 139. sumber pada kebiasaan masyarakat Iraq.[6]

Sedangkan fiqh yang ada di Indonesia masih merupakan fiqh impor (imported fiqh), artinya ada bagian-bagian fiqh yang digunakan di negara kita adalah fiqh yang diadopsi dari fiqh-fiqh Iraq, Hijaz, dan fiqh Timur Tengah lainnya. Sehingga perkembangan fiqh di Indonesia kurang mendapat respon yang baik. Hal ini menjadikan fiqh yang ada tidak berdasarkan pranata sosial Indonesia dan tentunya menjadi tidak sesuai dan tidak memasyarakat ketika diterapkan.

Padahal menurut Teuku M. Radhie salah satu syarat agar sebuah hukum dapat berlaku dengan baik dalam masyarakat, ialah bahwa hukum tersebut harus sesuai dengan aspirasi dan kebutuhan masyarakat.[7] Agar fiqh dapat diterima dan digunakan oleh masyarakat Indonesia maka merupakan tanggungjawab ulama untuk mengembangkan fiqh dan mencari pendapat yang sesuai dengan watak dan tabiat masyarakat Indonesia dan dengan alur pikir yang sezaman.

Dengan perspektif di atas, jika kemudian diproyeksikan untuk mengembangkan fiqh yang bersumber pada pranata sosial khas Indonesia, maka dengan pasti akan dapat menampung seluruh kemaslahatan yang dibutuhkan oleh masyarakat, serta menjadi bibit bagi pembangunan hukum Nasional di Indonesia.

Sehingga dapat difahami bahwa ijtihad pada era kontemporer ini menjadi sebuah keharusan, disamping merupakan fardhu kifayah yang dibebankan kepada umat Islam.[8] Golongan Hanbali dan ulama-ulama pengikut beliau, berpendapat bahwa tidak boleh pada setiap masa vakum dari seorang mujtahid yang dapat dijadikan rujukan oleh masyarakat dalam persoalan-persoalan yang muncul di tengah-tengah mereka. Seorang mujta-

[6]T.M Hasbie Ash Shiddiqiey, Syariat Islam Menjawab Tantangan Zaman (Yogyakarta: IAIN Suka, 1961), 41-42.

[7]Teuku Muhammad Radhie, Peranan Hukum Islam Dalam Pembinaan Hukum Nasional (Yogyakarta: tnp, 1983), 11.

[8]Yusuf Al-Qardhawi, Ijtihad Kontemporer (Kode Etik dan Berbagai Penyimpangan) (Surabaya: Risalah Gusti, 1995), 15. 
hid ketika itu harus memberikan fatwa bagi mereka yang berkenaan dengan masalahmasalah tersebut, berdasarkan pertimbangan syara' yang hukumnya diambil dari dalil-dalil yang terperinci.[9]

Meskipun fatwa itu tampaknya sederhana, namun dibalik kesederhanaan tersebut terdapat suatu jaringan kehidupan yang sangat rumit. Ketika proses diferensial bidang keahlian dan lapangan kehidupan semakin tajam, yang menimbulkan berbagai masalah hukum, maka frekwensi fatwa semakin kerap dan intens. Di Indonesia dikenal sebuah organisasi masyarakat yang mengeluarkan fatwa-fatwa sebagai respon permasalahanpermasalahan yang muncul di tengah-tengah masyarakat.[10]

Pelaksanaan hukum Islam di Indonesia ini telah diwakili salah satunya oleh MUI (Majelis Ulama Indonesia) yang kini lebih dikenal masyarakat sebagai lembaga yang berusaha menyelesaikan banyak permasalahan agama dengan mengeluarkan fatwa.[11] Keberadaan MUI ini merupakan andil dan bentuk tanggungjawab sekumpulan ulama terhadap berbagai perkembangan masalah dalam masyarakat.

Selain itu keberadaan MUI juga menjadi sebuah subjek yang menjaga ke-awet-an terhadap perkembangan hukum Islam yang terus mengalami corak modifikasi, pengembangan bahkan pembaharuan dari embrio yang berbentuk legal theory (madzhab) sebagai landasan pemikiran yang digunakan mufti (jurist consult) atau mujtahid fil madzhab, sehingga perkembangan pemikiran hukum Islam mengalami kontinyuitas.

Menurut Amri Mu'allim dan Yusdani, bahwa dinamika hukum Islam dari modifikasi, perkembangan hingga mengalami perubahan yang berakar dari pemikiran-pemikiran sebelumnya menjadi sebuah pandangan yang otoratif yang

[9]Yusuf Al-Qardhawi, Ijtihad, 23.

[10]Cik Hasan Basri, Pilar-Pilar Penelitian Hukum Islam dan Pranata Sosial (Jakarta: P.T Rajagrafindo Persada, 2004), 92.

[11]Jaih Mubarok, Metodologi Ijtihad Hukum Islam (Yogyakarta: UII Press, 2002), 169. dalam sejarah ushul fiqh disebut Al-Quwwatul Ma'rifiyah atau epistemic authorithy, yakni suatu pandangan yang secara keilmuan legitimit dan dapat dipertanggung jawabkan serta menjadi pegangan bagi generasi berikutnya.[12]

Adapun terbentuknya MUI di Indonesia memiliki sejarah yang cukup panjang, pada dasarnya MUI bukanlah himpunan ulama pertama yang muncul di Indonesia. Kembali lagi pada sejarah, bahwa pada masa penjajahan Belanda telah ada sejumlah organisasi daerah dan nasional yang memakai sebutan ulama, seperti Persyarikatan Ulama Majalengka, Persatuan Ulama seluruh Aceh, Majelis Ulama Indonesia Toli-Toli, dan Nahdlatul Ulama(NU). Dalam dasawarsa tiga puluhan organisasiorganisasi tersebut melebur menjadi satu dengan nama MIAI (Majelis Islam A'la Indonesia). [13] Pada masa kependudukan Jepang MIAI dibubarkan dan diganti Masyumi yang kemudian menjadi partai politik. Tahun 1960, presiden Soekarno membubarkan Masyumi,[14] sehingga para ulama harus mengundurkan diri dari panggung politik formal, dan hanya beberapa ulama NU saja yang masih bertahan oleh karena berada di bawah naungan Soekarno.

Pada masa pemerintahan Orde Baru era Soeharto, dengan mudah desakan untuk membentuk kembali himpunan semacam majelis ulama nasional terwujudkan di atas dalih yang mengandung berbagai kebutuhan politik. Pengajuan rancangan pembentukan MUI sebenarnya telah ada sejak tahun 1970, namun disebabkan dukungan pemerintah Soeharto disebut sebagai upaya pemanfaatan terbentuknya lembaga ini akan menjadikan lembaga ini tidak bebas intervensi pemerintah, sedangkan ulama merupakan bagian masyarakat dengan pemberian fatwa-fatwa sebagai tugas utama pembentukan lembaga ini yang harus berdiri secara independen tanpa intervensi pihak manapun. Sehingga adanya MUI saat itu ditebak sebagai bagian dari strategi pemerintah untuk memperoleh dukungan kaum muslimin atau sebagai kendali kaum muslimin.

[12]Amir Mu'allim dan Yusdani, Ijtihad, viii.

[13]Mohammad Atho Mudzhar, Fatwa-Fatwa 55.

[14]Majelis Syuro Muslimin Indonesia, (online), (http://wikipedia.com) Diakses 7 Mei 2010. 
Setelah desakan dari banyak pihak tepat pada tanggal 26 Juli 1975 MUI resmi terbentuk melalui Muktamar dan deklarasi "PIAGAM BERDIRINYA MUI" yang ditanda tangani oleh 53 orang peserta,[15] dengan ketua umum terpilih Dr. Hamka. Menurut Dr. Hamka alasan tepat menerima tawaran tersebut adalah; (1) sebagai langkah balik melawan ideologi komunis di Indonesia, maka harus menggunakan ideologi yang lebih kuat pula yakni ideologi Islam, dan untuk itulah maka kaum muslim selayaknya dapat bekerja sama dengan pemerintahan Soeharto, yang juga antikomunis. (2) Adanya sikap saling curiga antara pemerintah dan kaum muslim dalam usaha pembelaan negara sudah saatnya dihapuskan.[16]

Momentum berdirinya MUI bertepatan ketika bangsa Indonesia tengah berada pada fase kebangkitan kembali, setelah 30 tahun merdeka, di mana energi bangsa telah banyak terserap dalam perjuangan politik kelompok dan kurang peduli terhadap masalah kesejahteraan rohani umat.

Ulama Indonesia menyadari sepenuhnya bahwa mereka adalah pewaris tugas-tugas para Nabi (Warasatul Anbiya). Maka mereka terpanggil untuk berperan aktif dalam membangun masyarakat melalui wadah MUI, seperti yang pernah dilakukan oleh para ulama pada zaman penajajahan dan perjuangan kemerdekaan. Di sisi lain umat Islam Indonesia menghadapi tantangan global yang sangat berat. Kemajuan sains dan teknologi yang dapat menggoyahkan batas etika dan moral, serta budaya global yang didominasi Barat, serta pendewaan kebendaan dan pendewaan hawa nafsu yang dapat melunturkan aspek religiusitas masyarakat serta meremehkan peran agama dalam kehidupan umat manusia.

Selain itu kemajuan dan keragaman umat Islam Indonesia dalam alam pikiran keagamaan, organisasi sosial dan kecenderungan aliran dan aspirasi politik, sering mendatangkan kelemahan dan

[15]HYPERLINK "http://www.MUI.or.id/" www.MUI.or.id diakses pada tanggal 10 Mei 2009.

[16]Mohammad Atho Mudzhar Fatwa-Fatwa, 56. bahkan dapat menjadi sumber pertentangan di kalangan umat Islam sendiri.

Akibatnya umat Islam dapat terjebak dalam egoisme kelompok (ananiyah hizbiyah) yang berlebihan. Oleh karena itu kehadiran MUI, makin dirasakan kebutuhannya sebagai sebuah organisasi kepemimpinan umat Islam yang bersifat kolektif dalam rangka mewujudkan silaturrahmi, demi terciptanya persatuan dan kesatuan serta kebersamaan umat Islam.

Dalam perjalanannya, selama tiga puluh lima tahun Majelis Ulama Indonesia sebagai wadah musyawarah para ulama, zu'ama dan cendekiawan muslim berusaha untuk memberikan bimbingan dan tuntunan kepada umat Islam dalam mewujudkan kehidupan beragama dan bermasyarakat yang diridhoi Allah Subhanahu wa Ta'ala., memberikan nasihat dan fatwa mengenai masalah keagamaan dan kemasyarakatan kepada Pemerintah dan masyarakat, meningkatkan kegiatan bagi terwujudnya ukhwah Islamiyah dan kerukunan antar-umat beragama dalam memantapkan persatuan dan kesatuan bangsa serta menjadi penghubung antara ulama dan umaro (pemerintah) dan penterjemah timbal balik antara umat dan pemerintah guna mensukseskan pembangunan nasional meningkatkan hubungan serta kerjasama antar organisasi, lembaga Islam dan cendekiawan muslimin dalam memberikan bimbingan dan tuntunan kepada masyarakat khususnya umat Islam dengan mengadakan konsultasi dan informasi secara timbal balik. Dalam khitah pengabdian Majelis Ulama Indonesia telah dirumuskan lima fungsi dan peran utama MUI yaitu; (a) Sebagai pewaris tugas-tugas para Nabi (Warasatul Anbiya), (b) Sebagai pemberi fatwa (mufti), (c) Sebagai pembimbing dan pelayan umat (Riwayat wa khadim al ummah), (d) Sebagai gerakan Islah wa al Tajdid, (e) Sebagai penegak amar ma'ruf dan nahi munkar.

\section{Hasil}

Negara Indonesia yang bukan merupakan negara sekuler, meski tidak bisa disebut juga sebagai negara agama, merupakan negara berdasarkan Pancasila yang dibangun sebagai negara modern yang demokratis tetapi tetap menjunjung tinggi posisi agama 
dalam masyarakat dan negara. Hal ini membawa implikasi, bahwa hubungan atau tanggung jawab negara terhadap agama tidak hanya sebatas memberi perlindungan kebebasan beragama kepada para pemeluk agama sebagaimana terjadi pada negara-negara sekuler, tetapi juga memberikan pelayanan terhadap pemeluk agama dan melindungi kemurnian ajaran agama dari penyelewengen atau penyimpangan. Dalam hal ini Departemen Agama merupakan lembaga negara yang secara teknis melaksanakan tugas dan tanggung jawab ini.

Dalam Implementasi tugas tersebut yang berkaitan dengan urusan umat Islam, Departemen Agama bekerjasama dengan Majelis Ulama Indonesia (MUI), terutama dalam hal penentuan hukum keagamaan. Bagaimanapun Departemen Agama tidak mempunyai otoritas dalam penentuan hukum keagamaan tersebut. Di sisi lain, MUI sebagai sebuah wadah para ulama dan cendekiawan Muslim yang berasal dari ormas dan kelembagaan Islam selama ini telah diakui sebagai representasi umat Islam, yang mempunyai otoritas memberikan fatwa atau pertimbangan kepada pemerintah atau negara dalam hal-hal yang terkait dengan agama dan umat Islam.

Pengakuan ini misalnya dapat dilihat dalam UU tentang Pangan, yang salah satu pasalnya terkait dengan pencantuman tanda halal dalam kemasan produk makanan, minuman, kosmetika dan obatobatan, harus didasarkan atas fatwa halal dari MUI.[17]

Hal tersebut merupakan gambaran bahwasanya MUI adalah institusi yang berfungsi memberikan fatwa dan nasehat mengenai masalah keagamaan dan kemasyarakatan kepada pemerintah dan umat Islam pada umumnya sebagai amar ma'ruf nahi munkar dalam usaha meningkatkan ketahanan Nasional. Dengan demikian keberadaan MUI memiliki pengaruh yang cukup kuat dalam pembangunan citra pemurnian ajaran Islam khususnya dalam parktik keagamaan di kalangan umat Islam Indonesia.[18] Selain itu juga memiliki andil yang signifikan dalam pem-

[17]Mohammad Atho Mudzhar Fatwa-Fatwa, 56.

[18]H.M Hasbi Umar, Nalar Fiqh Kontemporer (Jakarta: Gaung Persada Press, 2007), 250-251. baharuan pemikiran hukum Islam sebagai langkah pembangunan hukum Nasional di Indonesia.

Di samping fungsinya tersebut, MUI merupakan pengawas dan melakukan kontrol terhadap peraturan dan undang-undang yang dibuat oleh pihak pemerintah.[19] Fatwa yang diberikan oleh MUI pada masyarakat Indonesia sedikit-banyak telah mendorong sebagian dari mereka, sekalipun yang bukan dari golongan peminta fatwa untuk melaksanakannya. Menurut Muzakki dalam artikelnya, bahwa fatwa MUI bisa bergerak menjadi sebuah instruksi terhadap sebagian kalangan masyarakat.[20]

Namun, Menurut hemat penulis hal semacam ini adalah tergantung kepada objek penerima fatwa karena pada dasarnya fatwa tidaklah mengikat dan MUI pun tidak mewajibkan dan mengklaim bahwa fatwanya adalah sebuah keharusan atau instruksi yang wajib dijalankan, namun juga tak dapat dielak bahwa keberadaan MUI dengan produk-produk fatwanya memang memberi pengaruh terhadap sebagian masyarakat Indonesia, seperti halnya konteroversial yang muncul dikemudian hari pasca keluarnya beberapa fatwa MUI, seperti pengharaman rokok, hair extension, dan rebonding. sekalipun keputusan fatwa tidak mengikat hukumnya, tetap saja adanya fatwa keharaman tersebut dirasa tidak relevan dengan beberapa aspek yang ada oleh sebagian golongan masyarakat.

Dalam metode pengambilan hukum, MUI menjadikan Al-Qur'an dan Al-Hadist sebagai sumber rujukan utama. Ayat-ayat Al-Qur'an yang perlu penafsiran, ditafsirkan sesuai dengan kaidah-kaidah penafsiran Al-Qur'an yang telah ada. Begitu pula dengan Hadist, kemudian nash Al-Qur'an dan Hadist dipertimbangkan dengan hasil pengembangan ilmu pengetahuan dan teknologi.[21] Sehingga, penafsiran MUI tersebut merupakan penafsiran kontekstual, dengan memperhatikan aspek ekstem atau konteks kekinian disamping konteks asbabun nuzul ayat atau azbabul wurud hadist.

[19]H.M Hasbi Umar, Nalar, 251.

[20]HYPERLINK "http://gusdur.net/" http:// gusdur.net diakses pada tanggal 10 Mei 2009.

[21]H.M Hasbi Umar, Nalar Fiqih, 251. 
Kemudian penggunaan kaidah fiqhiyah, kerap digunakan oleh MUI dalam penyelesaian masalah fiqh yang ada. Kecermatan dan ketepatan dalam penggunaan kaidah Ushul Fiqh sangat diperhatikan oleh majelis ulama. Namun, dalam hal ini perlu diakui adanya beberapa kesalahan atau kekurang tepatan penggunaan istilah, seperti daruriy yang kadang dicampur adukan dengan istilah hajat. Seperti yang terdapat dalam pernyataaan MUI mengenai kebolehan mengikuti Progran Perancang Keluarga.

Dalam setiap keputusan yang dikeluarkan, MUI berusaha menempatkan konsep kemaslahatan di dalamnya. Dengan demikian, kajian pencarian illat atau hikmah ditetapkannya hukum menjadi kajian utama dalam membahas masalah-masalah kontemporer. Berdasarkan itulah, metode pendekatan yang dilakukan menggunakan metodologi ta'lily, yakni dengan memperhatikan aspek maslahah, baik yang termasuk peringkat $d a$ ruriyyah, hajiyyah, maupun tahsiniyah. Pendekatan ini hampir selalu digunakan oleh MUI dalam membahas masalah-masalah kontemporer, sebagai akibat berkembangnya ilmu pengetahuan dan teknologi.

Selanjutnya, dalam menjalankan fungsinya sebagai majelis ulama, yang diberi amanah untuk memberikan fatwa-fatwa dan nasehat, serta memberikan jawaban hukum terhadap persoalan -persoalan baru, MUI melakukan kajian ijtihadi dengan kembali pada dalil-dalil syari'ah akan tetapi pemikiran yang ada diformulasikan dengan keadaan sezaman. Fatwa-fatwa fiqh dari MUI merupakan rekonstruksi pemikiranpemikiran yang telah ada dengan menjadikan landasan pemikiran kajian fiqh terdahulu (tarjih fatawa) dan pengujian validiti metode yang digunakan para ulama sebelumnya tersebut.[22]

Kendati demikaian, secara fungsi MUI telah dapat melaksanakan fungsi ijtihadnya, walaupun sebatas ijtihad tarjih dan sewaktu-waktu menggunakan ijtihad takhrij. Sebagai ciri fatwa yang kasuistis dan parsial, maka fatwa MUI tidak memiliki daya ikat bagi penataan kehidupan manusia, termasuk bagi peminta fatwa itu

[22]H.M Hasbi Umar, Nalar Fiqih, 254. sendiri. Ia hanya mengikat secara moral.[23]

Dari hasil kajian yang dilakukan[24], dalam ijtihadnya MUI menyelesaikan masalah-masalahnya dengan dua cara, diantaranya; Pertama, melakukan ijtihad tarjihi atau intiqa' $i$ yaitu, suatu ijtihad yang dilakukan seseorang atau sejumlah pakar untuk memilih pendapat para ahli fiqh terdahulu mengenai masalah tertentu yang serupa, kemudian menganalisis pendapat mana yang lebih kuat dalilnya dan lebih relevan dengan situasi dan keadaan sekarang. Hal yang menjadi faktor MUI dalam melakukan ijtihad tarjihi adalah memperhatikan perubahan sosial-budaya, kemajuan IPTEK dan tuntutan zaman. Hal inilah yang menjadi pertimbangan ketika menyelesaikan permasalahanpermasalahan yang muncul di tengah-tengah masyarakat.

Kedua, ijtihad insya'i atau ijtihad ibtida'i yakni suatu usaha untuk mengambili kesimpulan hukum mengenai kejadian-kejadian baru yang belum diselesaikan oleh ulama terdahulu. Ijtihad ini dilakukan oleh MUI terhadap masalah-masalah baru yang muncul dalam ijtihad ini diperlukan pemahaman yang menyeluruh terhadap kasus-kasus baru yang akan ditetapkan hukumnya.

Pedoman fatwa MUI ditetapkan dalam SK MUI No. U.596/MUI/ X/1997. Dalam SK tersebut, terdapat tiga bagian proses utama dalam menentukan fatwa, yaitu dasar-dasar umum penetapan fatwa, prosedur penetapan fatwa, dan teknik serta kewenangan organisasi dalam penetapan fatwa.

Dasar-dasar umum penetapan fatwa MUI ditetapkan pada pasal 2 ayat (1) dan (2). Pada ayat 1 dikatakan bahwa setiap fatwa didasarkan pada adillatu al-ahkam yang paling kuat dan membawa kemaslahatan bagi umat. Dalam ayat berikutnya, ayat (2) dijelaskan bahwa dasar-dasar fatwa adalah AlQur'an, Hadist, ijma', qiyas, dan dalil-dalil hukum lainnya. Sedangkan prosedur penetapan fatwa dilakukan dengan langkah-langkah berikut; (a) Setiap masalah yang diajukan kepada MUI dibahas dalam rapat komisi untuk mengetahui substansi dan duduk permasalahannya, (b) Dalam rapat komisi, dihadirkan ahli yang berkaitan dengan masalah

[23]Cik Hasan Basri, Pilar-Pilar, 48.

[24]H.M Hasbi Umar, Nalar Fiqih, 263-264. 
yang akan difatwakan untuk didengarkan pendapatnya sebagai pertimbangan, (c) Setelah pendapat ahli didengarkan dan dipertimbangkan, ulama melakukan kajian terhadap pendapat para imam madzhab dan fuqaha dan memperhatikan dalil-dalil yang digunakan dengan berbagai cara istidlal-nya dan segi kemaslahatannya bagi umat. Apabila pendapat-pendapat para ulama seragam atau hanya sebagian kecil ulama yang memiliki pendapat , komisi dapat menjadikan pendapat tersebut sebagai fatwa, (d) Jika fuqaha memiliki ragam pendapat, komisi melakukan pemilihan pendapat melalui tarjih dan memilih salah satu pendapat untuk difatwakan, (e) Jika tarjih tidak menghasilkan produk yang diharapkan, komisi dapat melakukan ilhaaqu al-masa'il bi nadhaa'irihaa dengan memperhatikan mulahaq bih,mulahaq ilayh, dan wajh ilahq (pasal 5), (f) Apabila cara ilhaq tidak menghasilakn produk yang memuaskan, komisi dapat melakukan ijtihad jama'i dengan menggunakan al-qawa'id al -ushuliyyat dan al-qawa'id al-fiqhiyyat.

Adapun kewenangan MUI adalah memberikan fatwa tentang; (a) Masalah-masalah keagamaan yang bersifat umum dan menyangkut umat Islam Indonesia secara nasional, (b) Masalah-masalah keagamaan di suatu daerah yang diduga dapat meluas ke daerah lain (pasal 10).

\section{KESIMPULAN DAN SARAN}

\section{Kesimpulan}

Melihat bahwa fiqh yang berkembang di Indonesia merupakan fiqh impor (imported fiqh) yang

\section{Daftar Pustaka}

Al-Qardhawi, Yusuf. 1995. Ijtihad Kontemporer (Kode Etik dan

Berbagai Penyimpangan). Surabaya: Risalah Gusti.

Ash-Shiddiqiey, T.M Hasbie. 1961. Syariat Islam Menjawab Tantangan Zaman. Yogyakarta: IAIN Suka.

Basri,Cik Hasan. 2004. Pilar-Pilar tentunya beberapa bagian fiqh di dalamnya masih bercorakkan sosial-kultur dari tempat asal pengadopsian hukum tersebut, sehingga dirasa kurang sesuai dan memasyarakat, maka dibutuhkan sebuah pembaharuan hukum, yang didalamnya tercakup modifikasi, pengembangan, dan perubahan. Selain itu karena zaman yang terus bergulir sehingga kebutuhan akan hukum dirasa semakin komplek dan intens.

Bertolak dari itu semua, keberadaan ulama sangat berperan dalam pengembangan hukum Islam sebagai pemenuh dan pengiring kebutuhan serta tuntutan permasalahan yang memerlukan solusi sekaligus jawaban di dalamnya. Sejalan dengan hal tersebut Majelis Ulama Indonesia (MUI) hadir sebagai wadah yang menampung berbagai permasalahan yang ada di tengah-tengah masyarakat Indonesia setelah sekian lama sejak masa penjajahan Belanda embrio lembaga ini telah ada, kemudian mengolah permaslahan tersebut dengan metode Ijitihad tarjihi dan Ijtihad insya' $i$ atau ijtihad ibtida' $i$, selanjutnya memproduk jawabannya sebagai fatwa yang sesuai dengan pranata sosial Indonesia.

Secara ringkas, keberadaan MUI ini sangat berperan bagi pengembangan hukum Islam dimasa modem seperti saat ini. Dimana peluang terkikisnya kepercayaan terhadap kesesuaian hukum Islam dan pengaplikasiannya dalam masyarakat sangat besar.Lebih dari hal itu, bahwa keberadaannya juga menjembatani hubungan pemerintah-masyarakat selain dari hubungan dalam arus politik khusus yang sedikit banyak telah melatar balaknagi kehadiran MUI di tengah-tengah masyarakat Indonesia.

\section{Penelitian Hukum Islam dan}

Pranata Sosial. Jakarta: P.T Rajagrafindo Persada.

Majelis Ulama Indonesia. 2003. Himpunan Fatwa Majelis Ulama Indonesia. Jakarta: Departemen Agama RI.

Mubarok, Jaih. 2002. Metodologi Ijtihad Hukum Islam. Yogyakarta: UII Press.

Mudzhar,Mohammad Atho. 1993. Fatwa- 
Fatwa Majelis Ulama Indonesia Sebuah Studi Tentang Pemikiran Hukum Islam di Indonesia. Jakarta: INIS.

Mu'allim, Amir dan Yusdani. 2005. Ijtihad dan Legislasi Muslim Kontemporer. Yogyakarta: UII Press.

Radhie, Teuku Muhammad. 1983. Peranan Hukum Islam Dalam Pembinaan Hukum Nasional. Yogya- karta: tnp.

Umar, H.M Hasbi. 2007. Nalar Fiqh Kontemporer. Jakarta: Gaung Persada Press.

Majelis Syuro Muslimin Indonesia, (online), (http://wikipedia.com) Diakses 7 Mei 2010. http://gusdur.net diakses pada tanggal $10 \mathrm{Mei}$ 2009.

www.MUI.or.id diakses pada tanggal $10 \mathrm{Mei}$ 2009. 